\title{
PERLINDUNGAN ANAK MENURUT HUKUM HINDU DAN UNDANG-UNDANG REPUBLIK INDONESIA NOMOR 23 TAHUN 2002
}

\author{
I Kadek Kartika Yase \\ IAHN Tampung Penyang \\ kadekkartika@iahntp.ac.id
}

\begin{abstract}
Abstrak
Setiap pasangan yang memasuki masa grahasta dan telah menjalani kehidupan rumah tangga tentu menantikan seorang anak dalam kehidupan mereka. Anak merupakan sebuah karunia atau anugerah dari Yang Maha Kuasa yang harus dijaga, dididik, dilindungi dan sebagainya oleh kedua orang tua maupun keluarganya. Seorang anak bersama kedudukannya mempunyai hak dan kewajiban dalam keluarga. Begitu halnya orang tua yang mempunyai kewajiban untuk membesarkan dan melindungi anaknya tanpa diiringi dengan perlakuan tidak baik yang dapat merugikan tumbuh kembang si anak. Diberbagai kitab Smerti seperti Manwa Dharmasastra, Sarasamuccaya dan Slokantara telah banyak menguraikan tentang anak. Misalnya dalam kitab Sarasamuccaya anak harus diperlakukan sebagai raja, kawan bahkan sebagai pelayan. Ini merupakan sebuah pendidikan kepada anak. Begitu halnya dalam Undang-Undang Republik Indonesia Nomor 23 Tahun 2005 Tentang Perlindungan Anak, berbagai definisi anak, perlakuan terhadap anak, perlindungan kepada anak dan sebagainya juga dijelaskan di dalamnya. Misalnya yang dimaksud dengan anak adalah seseorang yang belum berusia 18 (delapan belas) tahun, termasuk anak yang masih dalam kandungan. Seorang anak ahrus mendapat perlakuan yang baik dan perlindungan dari sejak dalam kandungan hingga lahir dan tumbuh dewasa. Seorang anak tidak boleh mendapat perlakuan diskriminasi dalam bentuk apapun. Tanggung jawab untuk memperlakukan anak dengan baik tidak hanya dilakukan oleh orang tua saja, melainkan masyarakat, pemerintah dan negara juga mempunyai tanggung jawab tersebut. Bagi siapapun yang yang memperlakukan anak tidak baik akan mendapatkan sanksi pidana sesuai dengan aturan yang berlaku.
\end{abstract}

Kata Kunci : Anak, Hukum Hindu 


\section{Pendahuluan}

Anak-anak merupakan generasi bangsa yang akan datang, kehidupan anak-anak merupakan cerminan kehidupan bangsa dan negara. Kehidupan anakanak yang diwarnai dengan keceriaan merupakan cerminan suatu negara memberikan jaminan kepada ank-anak untuk dapat hidup berkembang sesuai dengan dunia anak-anak itu sendiri, sedangkan kehidupan ank-anak yang diwarnai dengan rasa ketakutan, traumatik, sehingga tidak dapat mengembangkan psikososial anak, merupakan cerminan suatu negara yang tidak peduli terhadap anakanak sebagai generasi bangsa yang akan datang.

Anak mempunyai hak yang bersifat asasi, sebagaimana yang dimiliki orang dewasa, hak asasi manusia (HAM). Pemberitaan yang menyangkut hak anak tidak segencar sebagaimana hak-hak orang dewasa (HAM) atau isu gender, yang menyangkut hak perempuan. Perlindungan hak anak tidak banyak pihak yang turut memikirkan dan melakukan langkah-langkah kongkrit. Demikian juga upaya untuk melindungi hak-hak anak yang dilanggar yang dilakukan negara, orang dewasa atau bahkan orang tuanya sendiri, tidak begitu menaruh perhatian akan kepentingan masa depan anak. Padahal anak merupakan belahan jiwa, gambaran dan cermin masa depan, aset keluarga, agama, bangsa dan negara. Di berbagai negara dan berbagai tempat di negeri ini, anak-anak justru mengalami perlakuan yang tidak semestinya, seperti eksploitasi anak, kekerasan terhadap anak, dijadikan alat pemuas seks, pekerja seks anak, diterlantarkan, menjadi anak jalanan dan korban perang dan konflik bersenjata.

Masalah anak merupakan masalah yang amat serius dan membutuhkan peran serta dari semua pihak terkait untuk dapat mengatasi berbagai permasalahan yang muncul terhadapnya. Tidak hanya menjadi tanggung jawab pemerintah dan lembaga-lembaga sosial yang bergerak dalam bidang anak tetapi peran utama orang tua dan agama memegang peranan yang amat penting. Sebagai negara beragama, yang dimana segala aspek kehidupannya tidak bisa terlepas dari nilainilai ajaran agama sebagai landasan dasarnya termasuk dalam hal ini yaitu mengenai perlindungan terhadap anak. Yang menjadi pertanyaan besar sekarang adalah, adakah hukum atau aturan dari agama Hindu yang menyinggung tentang 
kedudukan serta upaya-upaya terhadap perlindungan hak-hak sebagai seorang anak atau genarasi penerus Hindu?

Secara fakta sejarah Agama hindu merupakan agama tertua di dunia, ini berarti agama Hindu merupakan agama yang paling lama mengalami perkembangannya hingga pada saat ini. Berdasarkan pada sumber-sumber hukum Hindu ternyata diketemukan bahwa agama Hindu melalui kitab-kitab hukumnya telah mengatur tentang anak baik itu kedudukan si anak ataupun hak-haknya yang patut mendapatkan perlindungan. Selain itu, selama anak itu belum menikah, maka anak tersebut berada dalam pengawasan orang tua. Selama masih dalam pengawasan orang tua, maka orang tua mempunyai kuasa terhadapa anakanaknya.

Ekasana (2012:121) menyatakan bahwa selama perkawinan orang tua berlangsung maka anak ada dalam kekuasaan kedua orang tuanya sampai anak itu menjadi dewasa. Kekuasaan orang tua hanya ada selama orang tua itu memenuhi kewajiban-kewajibannya terhadap anak-anak dengan baik. Untuk itu kedua orang tua wajib memelihara dan mendidik anak-anak mereka sebaik-baiknya. Dalam keluarga Hindu kehadiran seorang anak sungguh didambakan oleh kedua orang tua. Anak atau putra adalah buah akibat dari adanya proses perkawinan, karena itu anak dipandang sebagai tujuan hidup Grhasthasrama (berumah tangga). Kehadiran seorang anak memberikan kehangatan dan kebahagian seluruh anggota keluarga.

Raka Mas (2002:102) menyatakan bahwa melahirkan anak bukan semata-mata bertujuan untuk melanjutkan keturunan saja, tetapi mengandung maksud lain yaitu agar dapat menyelamatkan arwah leluhur dari api neraka. Jelaslah bahwa anak mempunyai peranan yang sangat penting dalam suatu keluarga. Kajeng dkk (2003:131) juga menyatakan bahwa "lagi pula, tidak kuasa kaum kerabat dan sanak keluarga memberi pertolongan, membebaskan dari kesedihan hati, begitupun emas dan segala rupa barang-barang milik, demikian kebangsawanan/kelahiran mulia, sastra dan mantra-mantra, demikian pula kekuasaan, keperkasaan, tidak dapat memberi pertolongan; yang dapat menolong, hanyalah tingkah laku susila, oleh karena sungguh-sungguh dapat melenyapkan kedukaan hati di dunia lain kelak kemudian” (Sarasamuscaya 165). 
Demikianlah melalui keturunan (antara lain anak) yang Susila dapat menyelamatkan para leluhur dari penderitaannya di akhirat. Sungguh besar peranan seorang anak bagi para leluhur, apalagi jika anak itu adalah anak yang Suputra. Kedudukan seorang anak dalam keluarga Hindu, yang mempunyai peranan yang sangat penting. Selain untuk melanjutkan keturunan, anak juga yang akan membebaskan roh para leluhur dari api neraka. Untuk itu sudah selayaknya seorang anak dipelihara dan dididik dengan baik oleh orang tuanya, serta mendapatkan perlindungan dari berbagai bentuk tindak kekerasan dari siapapun. Hukum positif dan hukum Hindu sudah diatur mengenai perlindungan terhadap anak.

\section{PEMBAHASAN}

\section{A. Hak Dan Kedudukan Anak}

Anak merupakan hasil perkawinan dari suami istri. Anak juga merupakan penerus keturunan keluarga dan sebagai generasi penerus bangsa, tonggak estapet pemimpin berikutnya. Chulsum dan Novia (2006:40) menyatakan bahwa anak adalah keturunan dari ayah dan ibu (keturunan yang kedua). Sehingga anak menjadi bagian dari keluarga tersebut, yang tentunya merupakan darah daging dari kedua orang tua mereka. Ekasana (2012:95) meyatakan bahwa dalam bahasa Sasekerta anak disebut dengan putra. Secara etimologi putra terdiri dari dua kata, masing-masing kata Put yang berati neraka, dan kata trayati yang berasal dari akar kata kerja kelas $\mathrm{X}$ parasmaipadam tr (berarti menolong, menyeberang) yang ditambah dengan aya sehingga menjadi pangkal presen traya dan ditambah dengan akhirantanda orang (a.t.o) ketiga tunggal ti, sehingga menjadi trayati (ia yang menolong, atau ia yang menyeberangkan). Kata Put disamadikan dengan trayati terjadilah kata Putrayati artinya Ia yang menolong atau menyeberangkan dari neraka.

Ajaran agama Hindu telah menunjukan bahwa seorang anak sangat diharapkan kehadirannya dalam sebuah keluarga dan seorang anak juga mempunyai kewajiban yang sangat besar, yaitu menjadi anak yang Suputra, yang akan bertanggung jawab kepada orang tua dan yang terpenting adalah kepada leluhurnya. Dimana dalam agama Hindu yang mempunyai kewajiban demikian 
adalah anak Purusa atau anak yang Sentana. Selain itu bertangung jawab kepada orang tua maupun leluhurnya, juga akan menjadi pewaris dan penerus keluarga.

Terkait dengan hal tersebut di atas, harus sesuai dengan ketentuan atau pedoman (hukum) yang berlaku dalam ajaran agama Hindu. Telah jelas bahwa hukum adalah sebuah aturan atau norma yang berlaku di dalam masyarakat. Hukum itu akan ada jika ada individu manusia yang membentuk kelompok dalam suatu wilayah tertentu. Hukum adalah peraturan yang berupa norma dan sanksi yang dibuat dengan tujuan untuk mengatur tingkah laku manusia, menjaga ketertiban, keadilan, mencegah terjadinya kekacauan. Hukum memiliki tugas untuk menjamin bahwa adanya kepastian hukum dalam masyarakat. Oleh sebab itu setiap masyarat berhak untuk memperoleh pembelaan didepan hukum. Hukum dapat diartikan sebagai sebuah peraturan atau ketetapan/ ketentuan yang tertulis ataupun yang tidak tertulis untuk mengatur kehidupan masyarakat dan menyediakan sanksi untuk orang yang melanggar hukum. Hukum Hindu adalah sebuah tata aturan yang membahas aspek kehidupan manusia secara menyeluruhyang menyangkut tata keagamaan, mengatur hak dan kewajiban manusia baik sebagai individu maupun sebagai mahluk sosial, dan aturan manusia sebagai warga negara (tata negara). Hukum Hindu juga berarti perundangundangan yang merupakan bagian terpenting dari kehidupan beragama dan bermasyarakat, ada kode etik yang harus dihayati dan diamalkan sehingga menjadi kebiasaan-kebiasaan yang hidup dalam masyarakat.

Menurut fakta sejarah Agama Hindu adalah agama pertama sekaligus tertua di dunia yang lahir dan berkembang di lembah sungai Sindhu, India. Agama Hindu memilki Weda sebagai kitab suci dan sumber ajaran utama bagi umatnya. Kitab suci Weda memuat berbagai aspek dalam relung sendi kehidupan manusia mulai dari aspek religi (hubungan dengan Tuhan sebagai pencipta segala yang ada), aspek ekonomi, politik dan kehidupan sosial masyarakat khususnya masyarkat Hindu dan masyarakat dunia secara umum. Hal ini dikarenakan ajaranajaran agama Hindu yang bersifat Universal dan fleksibel dan terbuka bagi setiap umat manusia. Tidak hanya sampai disana, Weda ternyata juga mengkaji tentang anak yaitu mengenai kedudukan serta berbagai upaya-upaya perlindungan 
terhadap anak yang tertuang dalam beberapa kitab-kitab bagian dari kitab Weda sebagai sumber ajaran utama bagi Umat Hindu.

Sarasamuccaya sloka 228, menyebutkan bahwa "yang dianggap anak adalah orang yang menjadi pelindung dari orang yang memerlukan pertolongan serta sebagai penolong kaum kerabat yang tertimpa penderitaan” . Begitulah kedudukan anak yang menduduki posisi yang amat penting dalam suatu keluarga menurut Hukum Hindu. Untuk itu sudah selayaknya seorang anak mendapatkan kasih sayang dari orang tuanya hingga anak tersebut dewasa. Selain itu si anak juga berhak mendapatkan pendidikan. Hal ini juga seperti yang dijelaskan oleh Ekasana (2012: 112) yang menyatakan bahwa:

"Hak ini dalam pasal Navano dyayah dan pasal 148 Pancamo dhyayah Veda Smerti disebutkan, bahwa anak-anak yang belum dewasa mempunyai hak untuk mendapatkan perlindungan dan tanggungan dari orang tua atau ayahnya, dan orang tua atau seorang ayah wajib melindungi anak-anaknya yang belum dewasa. Hak untuk mendapat perlindungan, maksudnya bahwa ank-anak itu benar-benar dirawat sampai dengan dewasa, dipenuhi kebutuhan kesehatannya. Hak untuk mendapatkan tanggungan maksudnya yaitu anak harus mendapat tanggungan untuk mendapatkan pendidikan dan memenuhi kebutuhan hidupnya".

Sebelum anak menginjak pada usia dewasa, anak tersebut mendapatkan semua haknya sebagai anak sesuai dengan ketentuan-ketentuan yang berlaku, baik secara Hukum Hindu maupun Hukum Nasional. Hak untuk mendapatkan pendidikan juga berdasarkan pasal 31 ayat 1 undang-undang dasar 1945 yaitu setiap warga negara berhak mendapat pendidikan (Rhedbook Publisher, 2013:34). Pendidikan yang diwajibkan oleh Pemerintah adalah 12 tahun.

Pudja dan Sudharta (2012:564) menyatakan bahwa "oleh karena seorang anak yang akan menyeberangkan orang tuanya dari neraka yang disebut Put (neraka lantaran tak memiliki keturunan), karena itu ia disebut putra" (Manawa Dharmasastra IX.138). Dari sloka tersebut dijelaskan bahwa anak atau putra menduduki posisi yang amat penting yaitu yang akan menyebrangkan orang tuanya dari neraka. Karena pada hakekatnya anak merupakan penerima serta penerus hak dan kewajiban orang tuanya. Untuk itu anak harus dijaga, dirawat, dipelihara oleh orang tua. Lebih lanjut Sudharta dan Tjokorda Rai (2012:77) menyatakan sebagai berikut: 
Rajawat panca warsesu dasa warsesu dasawat,

Mitrawat sodasawarsa ityrtat ptrasasanam.

Kalingannya, dening anibakna wrah-wrah ring anak, yan lima ng tahun tuwuhnya, kadi dening angiring anak sang prabhu dening anibaken warah irinya, matuha pwa ya ikang swaputra, kateka ring sadasa tahun tuwuhnya, irika ta yan warah hulun dening anibaken warah-warah irinya, kunang yan atuhu ikang anak, kateka ring nembelas tahun tuwuhnya, ika ta yan kadi dening amarah-amarah ing mitra dening anibaken warah-warah irinya, mangkana krama ning marah-marah putra, ling sang hyang aji.

Artinya:

Sampai umur lima tahun, orang tua harus memperlakukan anaknya sebagai raja. Dalam sepuluh tahun berikutnya sebagai pelayanan dan setelah umur enam belas tahun ke atas harus diperlukan sebagai kawan.

Perlakuan orang tua terhadap anak-anaknya ialah sebagai berikut: selama lima tahun dari bayi ia harus diperlakukan sebagai raja. Ketika anak itu bertambah umur sepuluh tahun lagi ia harus dilatih sebagai pelayan. Dan jika setelah anak itu berumur enambelas ia harus diperlakukan sebagai kawan terhadap kawan.

Inilah cara mendidik anak (Slokantara 22 (48)).

Penjelasan di atas menguraikan sewaktu anak itu masih kecil harus diperlakukan seperti raja, disanjung dan dipuji, lalu perintahkan kemudian diberi tahu dengan isyarat atau contoh dan bukan dinasehati dengan bertele-tele hingga menjemukan. Setelah anak dewasa maka anak itu bisa dijadikan sebagai teman dalam hidup. Ada perlakuan yang berbeda terhadap anak dari masa anak-anak sampai dewasa, dimaksudkan agar perkembangan anak terjaga dengan baik. Sehingga anak mempunyai kedudukan yang penting dalam sebuah keluarga dan mempunyai peran serta tanggung jawab yang sangat besar. Selain sebagai generasi penerus kuturunan keluarga, anak juga yang akan menolong Pitara/leluhurnya dari api neraka. Sehingga dalam keluarga Hindu anak itu harus diperlakukan dengan baik, apalagi anak itu seorang Purusa. 


\section{B. Perlindungan Anak Menurut Hukum Hindu}

Setiap anak yang beragama Hindu menurut hukum Hindu adalah sebagai subjek hukum Hindu, yang mempunyai hak-hak serta kewajibannya sebagai anak. Hak-hak sebagai subjek hukum Hindu pada umumnya diperoleh dari sejak yang bersangkutan masih dalam kandungan sampai dengan yang bersangkutan meninggal dunia. Selain hak dan kewajiban, seorang anak juga mempunyai peran terhdap keluarganya maupun sebagai generasi penerus bangsa secara umum. Sudharta dan Pudja (2012:62) menegaskan sebagai berikut:

Idanim dharma pramananyaha

Wedo'khilo dharmamulam

Smerticile ca tadwidam.

Acaraccaiwa sadhunam

Artinya:

Seluruh pustaka suci weda Sruti adalah sumber pertama dari pada dharma kemudian adat istiadat dan lalu tingkah laku yang terpuji dari orang-orang budiman yang mendalami ajaran pustaka suci weda, juga tata cara perikehidupan orang-orang suci dan akhirnya kepuasan dari pribadi (Manawa Dharmasastra, Buku II Sloka 6).

Menurut sloka diatas dijelaskan mengenai sumber-sumber hukum Hindu yang diantaranya yaitu:

1. Weda atau Sruti sebagai sumber pengetahuan utama yang didasarkan pada kemekaran intuisi para Maharsi penerima wahyu.

2. Smerti atau yang disebut dengan Dharmasastra.

3. Acara atau adat kebiasaan yang dipercayai serta dilaksanakan secara terus menerus dalam wilayah tertentu.

4. Sila yaitu tingkah laku terpuji dan luhur dari para Brahmana atau orang suci yang mendalami Weda atau orang-oarang yang berbudi pekarti luhur serta berpengetahuan suci.

5. Atmanastuti yaitu rasa kepuasan diri sendiri

Sumber-sumber hukum Hindu di atas merupakan sumber aturan utama yang dijadikan dasar dalam berperilaku dan bertindak bagi umat Hindu. Sumbersumber hukum tersebut mencakup berbagai aspek kehidupan manusia termasuk di 
dalamnya aspek anak dan perlindungan terhadapnya. Beberapa sloka yang berkaitan dengan anak dan sebagai salah satu dasar aturan bagi perlindungan anak menurut hukum Hindu antara lain:

a. Manawa Dharmasastra

Manawa Dharmasastra merupakan Compedium hukum Hindu, dimana memuat berbagai ketentuan bagi masyarakat Hindu dalam menjalani roda kehidupan. Diantara berbagai ketentuan tersebut telah diuraikan tentang anak dalam konsep ajaran Hindu. Manwa Dharmasastra Sloka 26 Dwitiyo Dhyayah menyatakan sebagai berikut :

Waisikah karmabhih punyair nisekadirdwijanmanam,

Karyah carira samskarah pawanah pretya ceha ca

Artinya:

Sesuai dengan ketentuan-ketentuan veda, upacara-upacara suci hendaknya dilaksanakan pada saat terjadinya pembuahan dalam rahim ibu serta upacara-upacara kemanusiaan lainnya bagi golongan triwangsa yang dapat mensucikan dari segala dosa dan hidup ini maupun setelah meninggal dunia (Sudharta dan Pudja, 2012:67).

Sloka ini menyatakan bahwa seorang anak mendapat jaminan berupa upacara penyucian semenjak dalam kandungan bahkan semenjak terjadinya pembuahan di dalam rahim ibu. Ditegaskan bahwa semenjak terjadi pembuahan, si anak sudah mendapatkan perhatian dan perlindungan dari orang tua serta pihakpihak lainnya berkewajiban untuk melindungi keberadaannya.

Kemudian Sloka 27 Dwitiyo Dhyayah Manwa Dharmasastra menyatakan sebagai berikut :

Garbhairhomairjatakarma caudamaujini bandhanah,

Baijikam garbhikam caino dwijanampamrjyate

Artinya:

Dengan upacara membakar bau-bauan harum pada waktu hamil sang ibu, dengan upacara jatakarma (bayi waktu lahir), upacara cauda (upacara gunting rambut pertama), dan upacara maunji bandhana (memberi kalung atau gelang) maka kekotoran yang didapat dari orang tua terhilang dari Triwangsa (Sudharta dan Pudja, 2012:67) 
Berdasarkan sloka di atas dijelaskan seorang anak mendapat jaminan terhadap perlindungan terhadapnya semenjak si anak berada di dalam kandungan si Ibu, saat si anak lahir, pemotongan rambut pertama hingga pada pemberian kalung dan gelang sebagai ungkapan rasa sayang dan cinta kasih orang tua terhadap si anak. Perlakuan demikian tentu mempunyai maksud dan tujuan yang baik terhadap anak yang dilahirkan oleh Ibunya.

Lebih lanjut sloka 3 Navano Dhyayah dan Sloka 148 Pancamo Dhyayah Manawa Dharmasastra yang menyebutkan sebagai berikut:

Pita raksati kaumare bhartta raksati yauvane,

Raksani sthavire putra na stri svatantryam arhati

Artinya:

Ayahnya akan melindunginya selagi ia masih kecil dan setelah dewasa suaminyalah yang melindungi dan melindungi putra-putranya setelah ia tua, wanita tak layak bebas (Sudharta dan Pudja, 2012:526).

Sloka 148 Pancamo Dhyayah Manawa Dharmasastra

Balye piturvase tisthet panigrahasya yauvane

Putranam bhartari prete na bhajet stri svatantratam

Artinya:

Pada waktu masih kanak-kanak seorang wanita menjadi tanggungan ayahnya, pada waktu berkeluarga tanggungan suaminya. Kalau suaminya meninggal menjadi tanggungan putra-putranya, seorang wanita hendaknya jangan bertindak sendiri (Sudharta dan Pudja, 2012:321).

Kedua sloka di atas menerangkan anak perempuan yang belum dewasa mempunyai hak untuk mendapatkan perlindungan dan tanggungan dari orang tua atau ayahnya, dan orang tua atau seorang ayah wajib melindungi anak-anaknya yang belum dewasa. Hak untuk mendapatkan perlindungan, maksudnya bahwa anak-anak itu harus benar-benar dirawat sampai dengan dewasa, dipenuhi kebutuhan kesehatannya. Hak untuk mendapat tanggungan untuk mendapatkan pendidikan dan memenuhi kebutuhan hidupnya. Selain memilki hak sebagai seorang anak juga mempunyai kewajiban yang wajb untuk dilaksanakan. Ketika anak perempuan tersebut dewasa dan sudah berkeluarga, maka tanggung jawab untuk melindunginya dibebankan kepada suaminya. 
b. Sarasamuscaya

Bagian dari Smerti lainnya yang terdapat penjelasan mengenai perlindungan anak yaitu kitab Sarasamuccaya. Misalnya termuat dalam sloka 243 yang menyebutkan:

Pritimatram pituh putrah sarvam putrasya vai pita,

Cariradini deyani pita tvekah prayacchati.

Ikang anak ngaranya, matraptining bapa ginawenya, kunang ikang bapa, sakwehning sukhaning anak ginawenya, apan tan hana tinengetning bapa, cariranira towi, winehakenira ta ya.

Artinya:

Yang disebut anak, patutnya membuat si bapak agar puas hatinya; sedangkan si bapak, sebanyak-banyaknya kesenangan si anak dikerjakan olehnya, sebab tidak ada yang dipikirkan si bapak, badannya sekalipun akan direlakan (Kajeng dkk, 2003:189).

Seorang bapak (orang tua si anak) berkewajiban untuk mengusahakan segala hal untuk kebahagian si anak. Orang tua berkewajiban dan memilki tanggung jawab atas kebahagian dan kesejahteraan si anak. Semua yang dilakukan oleh seorang bapak, tidak lain dan tidak bukan adalah untuk keluarganya terlebih khusus untuk si buah hatinya. Kehadirannya seorang anak tentu sangat diharapkan oleh kedua pasangan suami istri dalam menjalani rumah tangga. Tanpa kehadiran seorang anak, maka keluarga tersebut tidak akan lengkap. Oleh sebab itulah ketika seorang anak hadir di tengah-tengah keluarga, harus dijaga, dirawat, dididik dan sebagainya. Artinya mendapatkan perlakuan daan perlindungan semanamestinya. Tidak boleh sedikitpun mendapatkan perlakuan yang tidak baiak, apapun jenisnya.

Selanjutnya dalam kitab Sarasamuccaya sloka 244 menyatakan:

Samarthamasamartham va krcam capyakrcam tahta,

Raksatyeva sutam mata nanyah posta tathavidhah.

Mangkanang ibu, arata jugasihnira manak ya, apan wenang tan wenang, saguna, nirguna, daridra, sugih, ikang anak, kapwa rinaksanira, iningunira ika, tan hana ta pwa kadi sira, ring masiha mangingwana.

Artinya: 
Demikian si ibu, rata benar-benar cinta kasihnya kepada anak-anaknya, sebab baik cakap ataupun tidak cakap, berkebajikan atau tidak berkebajikan, miskin atau kaya anak-anaknya itu semua dijaga baik-baik olehnya, dan diasuhnya mereka itu; tidak ada yang melebihi kecintaan beliau dallam hal mengasihi dan mengasuh ank-anaknya (Kajeng dkk, 2003:190).

Sebagai orang tua tanpa memandang status sosial dan ekonominya orang kaya atau miskin, cakap maupun tidak cakap, berpendidikan atau tidak berpendidikan, wajib untuk menjaga, memelihara serta mengasihi dan mencintai anaknya karena sesungguhnya tiada cinta yang melebihi cinta kasih orang tua terhadap anaknya. Secara garis besar konsep Hindu telah mengjaarkan cinta kasih dilakukan kepada semua makhluk hidup ciptaan Tuhan Yang Maha Esa. Lebih lagi cinta kasih terhadap seorang anak yang merupakan darah dagingnya.

c. Slokantara

Slokantara sebagai salah satu kitab smerti yang dijadikan pedoman orang tua dalam mendidik anak. Di dalam Sloka 23 butir 49 Slokantara disebutkan bahwa:

\section{Lalanad bahawo dosastadanad bahawo gunah,}

\section{Tasmat putresu siayasu tadanam na tu lalanam.}

Kalinganya, ikang putra yan lalana, tuhun ika tan piniheran, tan warung mamangguh dosa, kunang ikang putra yan tinadana, tuhun iak yan sinakitan ing warah-warah, tan wurung ika mamangguh guna, matang yan ikang putra mwang sisya tadana nika, maran agong gunanya, haywa wineh lalana ling ning aji.

Artinya:

Banyak ketidakbaikan dan banyak pula kebaikan-kebaikan memarahi anak. Jadi yang perlu dilakukan terhadap anak atau murid, ialah hukuman dimana perlu dan bukan kemanjaan.

Jika anak itu selalu dimanjakan dan tidak pernah dilarang dalam hal apapun, akhirnya akan biasa pada apa yang salah. Jika anak itu dipukul dan dihukum sebagai bagian dari pendidikannya, pasti ia akan menjadi orang yang baik. Oleh karena seorang anak dan murid itu harus dihukum (dimana perlu) guna 
mencapai ketinggian pribadinya. Jangan dtunjukan rasa sayang yang berlebihan terhadapnya.

Disini dapat diartikan bahwa seorang anak berhak atas pengajaran dan pendidikan mengenai segala hal yang dianggap patut dan tidak patut serta jika ia bersalah si anak juga berhak atas hukuman yang tujuannya tiada lain untuk mendidik si anak agar menjadi anak yang berkepribadian, berkarakter dan berbudi pekerti luhur sehingga terwujud generasi atau putra yang suputra. Pendidikan anak dalam kitab Slokantara disebutkan"sampai umur 5 tahun, orang tua harus memperlakukan anak anak sebagai raja. Dalam sepuluh tahun berikutnya sebagai pelayan dan setelah umur 16 tahun sebagai kawan. Tidak hanya setalah lahir saja anak mendapatkan pendidikan seperti yang ttelah disebutkan. Namun sejak masih dalam kandungan sudah mendapatkan pendidikan, misalnya tidak boleh memarahi istri yang sedang hamil dan begitu seterusnya.

\section{Perlindungan Anak Menurut UU RI Nomor 23 Tahun 2002}

Anugerah terindah yang dinantikan oleh pasangan suami istri dalam membina rumah tangga adalah kehadiran seorang anak. Tanpa kehadiran seorang anak, keluarga tersebut tidak akan lengkap. Banyak pasangan yang tidak mempunyai anak/keturunan. Tidak ada yang melebihi kebahagiaan kehadiran seorang anak dalam keluarga dibandingkan yang lain. Dengan begitu bagi pasangan yang dikaruniai buah hati, perlakukanlah sesuai dengan kaidah-kaidah yang berlaku. Dalam Pasal 1 ayat 1 Undang-undang RI Nomor 23 Tahun 2002 tentang perlindungan anak menerangkan "anak adalah seseorang yang belum berusia 18 (delapan belas) tahun, termasuk anak yang masih dalam kandungan”. Kemudian ayat 2 menyebutkan "Perlindungan anak adalah segala kegiatan untuk menjamin dan melindungi anak dan hakhaknya agar dapat hidup, tumbuh, berkembang, dan berpartisipasi, secara optimal sesuai dengan harkat dan martabat kemanusiaan, serta mendapat perlindungan dari kekerasan dan diskriminasi”. Perlindungan kepada anak harus dilakukan sejak anak tersebut berada dalam kandungan. Tidak dibenarkan anak dalam kandungan mendapat perlakuan yang tidak baik dari siapapun, apalagi anak tersebut sudah lahir kedunia dan menjalani kehidupan seperti manusia pada umumnya. 
Maksud dilakukannya perlindungan terhadap anak sejak dalam kandungan hingga tumbuh dewasa, agar anak tersebut tumbuh dan berkembang secara baik sesuai dengan kedudukannya sebagai manusia dan terhindar dari perlakuan diskriminasi dalam bentuk apapun. Hal ini seperti bunyi Pasal 3 Undang-Undang RI Nomor 23 Tahun 2002 tentang perlindungan anak yaitu "Perlindungan anak bertujuan untuk menjamin terpenuhinya hak-hak anak agar dapat hidup, tumbuh, berkembang, dan berpartisipasi secara optimal sesuai dengan harkat dan martabat kemanusiaan, serta mendapat perlindungan dari kekerasan dan diskriminasi, demi terwujudnya anak Indonesia yang berkualitas, berakhlak mulia, dan sejahtera".

Sesungguhnya tidak hanya orang tua atau keluarga yang bertanggung jawab kepada anaknya, masyarakat dan Pemerintah serta negarapun mempunyai tanggung jawab kepada si anak. Misalnya negara memberikan peluang yang sama terhadap anak di bidang pendidikan, kesehatan dan lain sebagainya. Namun demikian halnya, yang utama tanggung jawab tersebut dibebankan kepada orang tua atau keluarganya. Hal ini dikarenakan orang tua atau keluarga adalah orang terdekat yang melahirkan, mendidik, membesarkan dan melindungi secara langsung. Tanggung jawab orang tua dan keluarga telah diuraikan pula dalam Undang-Undang RI Nomor 23 Tahun 2002 tentang perlindungan anak pasal 26 yaitu:

1) Orang tua berkewajiban dan bertanggung jawab untuk:

a. mengasuh, memelihara, mendidik, dan melindungi anak;

b. menumbuhkembangkan anak sesuai dengan kemampuan, bakat, dan minatnya; dan

c. mencegah terjadinya perkawinan pada usia anak-anak.

2) Dalam hal orang tua tidak ada, atau tidak diketahui keberadaannya, atau karena suatu sebab, tidak dapat melaksanakan kewajiban dan tanggung jawabnya, maka kewajiban dan tanggung jawab sebagaimana dimaksud dalam ayat (1) dapat beralih kepada keluarga, yang dilaksanakan sesuai dengan ketentuan peraturan perundangundangan yang berlaku. 
Telah ditegaskan pula sanksi hukum bagi siapapun yang berbuat tidak baik terhadap seorang anak. Hal ini mengisyaratkan anak harus diperlakukan sesuai ketentuan atau norma yang berlaku. Terkait dengan itu ada ketentuan pidana dalam Undang-Undang RI Nomor 23 Tahun 2002 tentang perlindungan anak salah satunya pasal 77 yaitu sebagai berikut:

Setiap orang yang dengan sengaja melakukan tindakan :

a. diskriminasi terhadap anak yang mengakibatkan anak mengalami kerugian, baik materiil maupun moril sehingga menghambat fungsi sosialnya; atau

b. penelantaran terhadap anak yang mengakibatkan anak mengalami sakit atau penderitaan, baik fisik, mental, maupun sosial,

c. dipidana dengan pidana penjara paling lama 5 (lima) tahun dan/atau denda paling banyak Rp 100.000.000,00 (seratus juta rupiah).

Demikian berbagai aturan atau ketentuan yang terdapat dalam UndangUndang Republik Indonesia Nomor 23 Tahun 2002 tentang perlindungan anak. Segala bentuk ketentuan yang terdapat di dalamnya harus ditaati dan dijalankan demi kebaikan si anak, orang tua maupun yang lainnya.

\section{PENUTUP}

Menurut Hukum Hindu anak menduduki posisi atau kedudukan yang amat penting dalam sebuah keluarga. Anak merupakan pelaksana hak dan kewajidan dari orang tua dan sebagai penerus keturunannya. Hak-hak sebagai subjek hukum Hindu pada umumnya diperoleh dari sejak dalam kandungan hingga lahir dan dalam perkembangan selanjutnya selama masih dalam masa anak-anak. Manawa Dharmasastra, Sarasamuccaya, dan Slokantara menegaskan bahwa orang tua berkewajiban untuk memberikan perlindungan bagi anak dalam segala hal meliputi bidang pendidikan, kesehatan maupun kesejahteraan sosial si anak.

Begitu halnya dalam Undang-Undang Republik Indonesia Nomor 23 Tahun 2005 tentang Perlindungan Anak yang dimaksud anak adalah seseorang yang belum berusia 18 (delapan belas) tahun, termasuk anak yang masih dalam kandungan. Perlindungan anak adalah segala kegiatan untuk menjamin dan melindungi anak dan hakhaknya agar dapat hidup, tumbuh, berkembang, dan 
berpartisipasi, secara optimal sesuai dengan harkat dan martabat kemanusiaan, serta mendapat perlindungan dari kekerasan dan diskriminasi. Bagi siapapun dapat dikenakan sanksi pidana jika seorang anak diperlakukan tidak baik dalam berbagai bentuk. Oleh karenanya seorang anak berhak mendapatkan perlakuan yang baik, kesempatan di berbagai bidang dan penghidupan yang layak.

\section{Daftar Pustaka}

Chulsum, Umi, dan Novia, Windy. 2006. Kamus Besar Bahasa Indonesia. Kashiko. Surabaya.

Ekasana, I Made Suastika. 2012. Dharma Bhandu (Hukum Kekeluragaan Hindu). Paramita. Surabaya.

Pudja, Gede, dan Sudharta, Tjokorda Rai. 2012. Manawa Dharmasastra. Widya Dharma. Denpasar.

Kajeng, I Nyoman, Dkk. 2003. Sarasamuccaya. Pustaka Mitra Jaya. Jakarta.

Raka Mas, A. A. Gede. 2002. Perkawinan Yang Ideal. Paramita. Surabaya.

Silalahi, Ulber. 2009. Metode Penelitian Ilmiah. PT Refika Aditama. Bandung.

Sudharta, Tjokorda Rai. 2012. Slokantara, Ajaran Etika: Teks, Terjemahan Dan Ulasan. ESBE Buku. Denpasar Timur.

Undang-Undang Republik Indonesia Nomor 23 Tahun 2005 Tentang Perlindungan Anak 